\title{
秋田石油備蓄西基地地中式原油タンクの設計・施工
}

\section{DESIGN AND CONSTRUCTION OF IN-GROUND OIL TANKS AT AKITA OIL STORAGE COMPANY LTD. WEST BASE}

\author{
永田英敏* ・植出和雄 $* *$. 久野英郷*** ・ 林 博一**** \\ By Hidetoshi NAGATA, Kazuo UEDE, Hidesato KUNO and Hirokazu HAYASHI
}

\begin{abstract}
Akita National Oil Reserve Base which has a total storage capacity of 4.5 million kilolitres is now under construction in Oga city in Akita prefecture. In this report the civil engineering works of four in-ground oil tanks which have a capacity of 305000 kilolitres each are introduced.

The tanks are now near completion using the usual lining method with soldier pile and rock anchor retaining walls in a mudstone stratum. The excavation work, which has a diameter of 96 meters and a depth of 39 meters, is one of the largest vertical excavation works in Japan. Focuses are mainly in the introduction of the design concept, the analysis of monitering during the excavation, and the evaluation of the design concept.

Keywords: in-ground oil tank, mudstone, excavation, observation construction, rock anchor
\end{abstract}

\section{1. まえがき}

現在，秋田石油備蓄株式会社は，国家石油備蓄計画の 一環として，秋田県男鹿市船川地区において西基地およ び東基地の備蓄基地を建設中である．本報告は，このう ち先発工事としてほぼ完成間近となっている西基地地中 タンク工事について，主に設計技術的な立場から，その 概要を取りまとめたものである.

秋田石油備蓄基地は, 昭和 56 年度に実施されたフィー ジビリティ・スタディに始まり, その後の各段階の技術 検討を経て, 最終的には, 施設配置上の制約および建設 地点の地質条件などから地中タンク方式を採用し, 西基 地で 30.5 万 $\mathrm{k} l$ タンク 4 基, 東基地で 35.3 万 $\mathrm{k} l$ タンク 8 基を建設し, 払出しタンク 4 基 $(44$ 万 $\mathrm{k} l)$ とあわせ て総貯蔵容量約 450 万 $\mathrm{k} l$ を備蓄する計画である.

地中タンクの施工法については, 順巻き工法, 逆巻き 工法, ケーソン工法等を中心に比較検討した結果, 親杭・

* 秋田石油備蓄 (株) 建設部調查役 （†105 港区虎門 3-5-1)

** 日鉱エンジニアリング(株)エンジニアリング事業部技師 長 (同上)

*** 正会員 鹿島建設(株)土木設計本部設計長 ( ₹163 新宿区西新宿 2-1-1)

**** 正会員 清水建設(株)土木本部設計部課長 （ T108 港区三田 3-13-16）

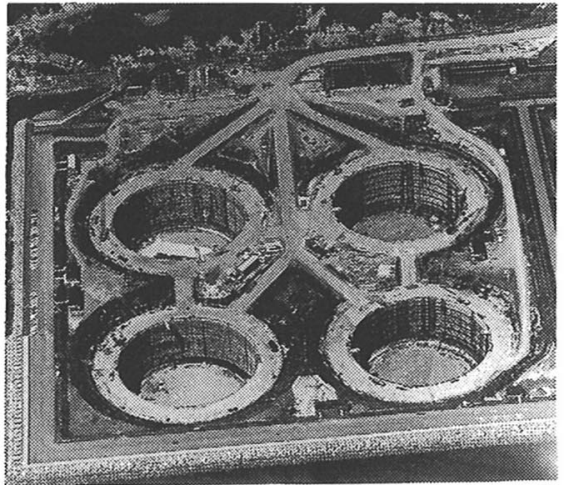

写真-1 西基地建設状況

ロックアンカー式山留めを用いた順巻き工法を採用して いる.

本工事は, 建設地点の地質を構成する新第三紀の海成 堆積岩 (泥岩, 頁岩等) を親杭・ロックアンカー等で支 保しながら, 直径約 $96 \mathrm{~m}$, 深さ約 $39 \mathrm{~m}$ の大規模鉛直掘 削を行った後に軀体を下部より構築するものであり, そ の規模, 難度からいってわが国でも第一級の掘削工事と いえよう. 特に, 泥岩地山はトンネル工事等で数多く報 告されているように掘削による応力解放やスレーキング により, 膨張や膨圧の発生, 強度の劣化を起こしやすい 
性質のため，土砂地山や硬岩地山に比べ特殊な配慮が必 要となる。

当地中タンクの基本計画段階においては，山留工およ びタンク軀体を設計するうえにおいても解決しなければ ならない次の問題があった。

（1）泥岩については, 強度・変形特性，およびその ひずみ依存性や時間依存性といった基本物性の把握がコ アサンプルを対象として解明されているものの, 地山全 体規模としての取扱い方が確立されていない。

（2）タンク軀体の大部分が岩盤中に構築されること から, 軀体と岩盤之の相互作用すなわち，岩盤部のばね 定数の評価や岩圧の評価が設計上重要な項目であるが, その手法が確立されていない。

ここでは,これらの懸案事項について調査段階で得ら れたデー夕をもとに評価検討を行って，山留工および軀 体の設計を実施したが，施工中の計測や確認調査で設計 の妥当性を確認することができたのでその概要を報告す る.

\section{2. 工 事 概 要}

\section{(1) 工事 概 要}

a) 地中タンクの概要

地中式原油タンクの位置図, 平面図, 構造図および主 要数量表を図一1〜3，表一 1 に示す.

主要寸法は内径 $\phi=90 \mathrm{~m}$, 液深 $h=48 \mathrm{~m}$ （容量 30.5 万 $\mathrm{k} l$ ) と地中式タンクとしては世界最大であり, 掘削 土量も 4 基合計で約 150 万 $\mathrm{m}^{3}$ となる. 本タンクは泥岩 中に設置されるため, 泥岩の大規模鉛直掘削 $(\phi=96 \mathrm{~m}$, $h=39 \mathrm{~m})$ を行った後, 順巻き工法により軀体を構築し た。また, 山留めは経済性を考慮し, 親杭・ロックアン カー式山留工法を採用した.

また泥岩中を浸透してくる涌水は排水砕石層 $(t=$ $1.2 \mathrm{~m})$ に導き, 各タンク 4 か所に設けられた集水槽か ら排水することで底版に水圧を作用させない構造とし， 底版厚さの低減と安全性の確保を図った。

地中式原油タンクは, 貯蔵油の圧力, 周辺岩盤の圧力, 地下水圧, 地震力等種々の内圧, 外圧を受け持つ鉄筋

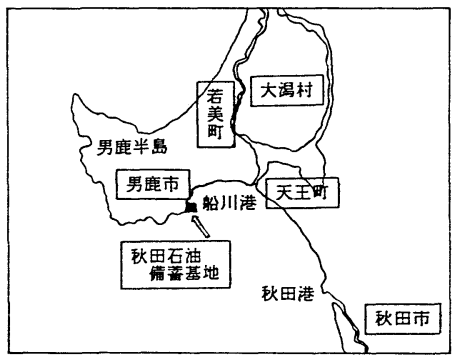

図-1 位置図
ンクリート造（側壁 $t=2.7 \mathrm{~m}$, 底版 $t=0.5 \mathrm{~m}$ ）の外款 と，その内側に設置する液密を保つためのライニング鋼 板から成り立つ。

タンク周辺には注水システムを設け，タンク周辺の水 位を一定に保つこととし，側壁にかかる水圧を均等にし て偏水圧を作用させない構造とした。

b) 地 質 概 要

男鹿半島南岸地域の地質は, 新第三紀の頁岩, 泥岩, シルト岩, 砂岩などから構成される厚い海成堆積岩層と なっている.この堆積岩の下には火山噴出物が累積して おり，さらに，この下部は先新第三紀の花崗岩質基盤岩 となっている.

建設地点である船川地区の地質は新第三紀船川層（層 厚約 600 800 m） に属し，暗灰色～黒灰色泥岩を主体 として灰色～灰白色凝灰岩・凝灰質砂岩亡互層をなして

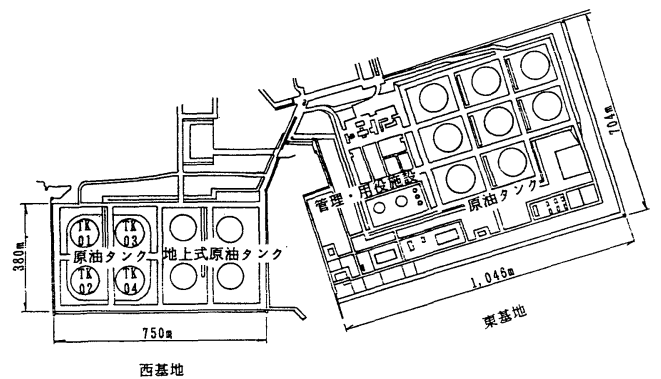

図一2 平面図

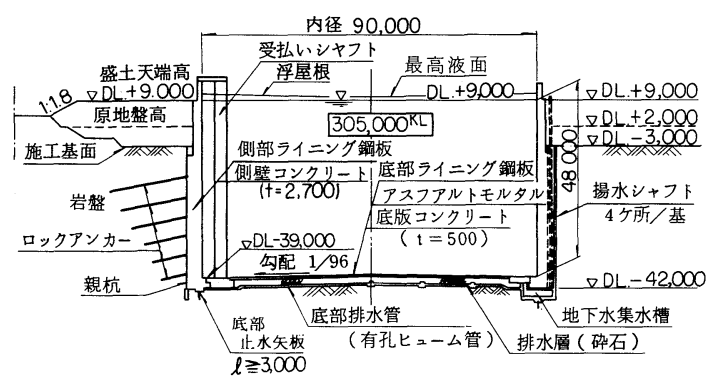

図一3 地中タンク構造図

表一1 土木工事主要数量表 (4 基分)

\begin{tabular}{|c|c|c|c|}
\hline & 事 & 数 量 & 備 \\
\hline $\begin{array}{l}\text { 山留め } \\
\text { 工事 }\end{array}$ & $\begin{array}{l}\text { ロックアンカー } \\
\text { ロックボルト } \\
\text { 吹付けコンクリート }\end{array}$ & $\begin{array}{r}1,795 \text { 本 } \\
7,963 \text { 本 } \\
45,583 \mathrm{~m}^{2}\end{array}$ & $\begin{array}{l}\text { SEEE工法、V S L工法 } \\
\mathrm{t}=80 \mathrm{~mm}\end{array}$ \\
\hline $\begin{array}{l}\text { 軀体 } \\
\text { 工事 }\end{array}$ & $\begin{array}{l}\text { 鉄 筋 } \\
\text { コンクリート } \\
\text { 砕 石 } \\
\text { アスファルトモルタル }\end{array}$ & $\begin{array}{l}12,292 \mathrm{t} \\
18,600 \mathrm{~m}^{3} \\
27,330 \mathrm{~m}^{3} \\
24,836 \mathrm{~m}^{2}\end{array}$ & $\begin{array}{l}\text { S D } 30 \text {, S D } 35 \\
\text { 側壁 } 300 \mathrm{Kg} / \mathrm{cm}^{2} \text {, 底版 } 240 \mathrm{Kg} / \mathrm{cm}^{2}\end{array}$ \\
\hline 土工事 & $\begin{array}{l}\text { 掘 削 } \\
\text { 埋戻し、盛土 }\end{array}$ & $\begin{array}{r}1,482 千 m^{3} \\
750 千 m^{3}\end{array}$ & 2 次掘削: $1,070{\text { 千 } m^{3}}^{3}$ \\
\hline
\end{tabular}


いる. 走行は $\mathrm{N} 60^{\circ} \mathrm{W} \sim \mathrm{E}-\mathrm{W}$ で傾斜は $5 \sim 10^{\circ} \mathrm{NE}$ を示 す. 地質断面を図一 4 に示す.

現位置試験および物理・化学試験等の室内試験を行っ た結果, この泥岩の特徴としては以下のとおりである.

(1) 岩盤区分 $C_{L} \sim C_{M}$

(2) $q_{U}=15 \sim 40 \mathrm{kgf} / \mathrm{cm}^{2}$

(3) 高いスレーキング性を示す.

(4) 吸水膨張性を若干有するがその程度はトンネル工 事などで問題となるような膨張性泥岩に比べて小 さい.

c) 工 程

工事工程を表一2に，工事フローを図一5に示す．昭 和 58 年 5 月に工事を開始し，60 年 10 月に掘削工事, 62 年 9 月に軀体工事, 63 年 10 月に盛土工事を完了し, 現在は付帯工事を残すのみである.

地 管 凡例

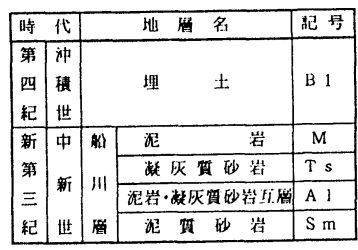

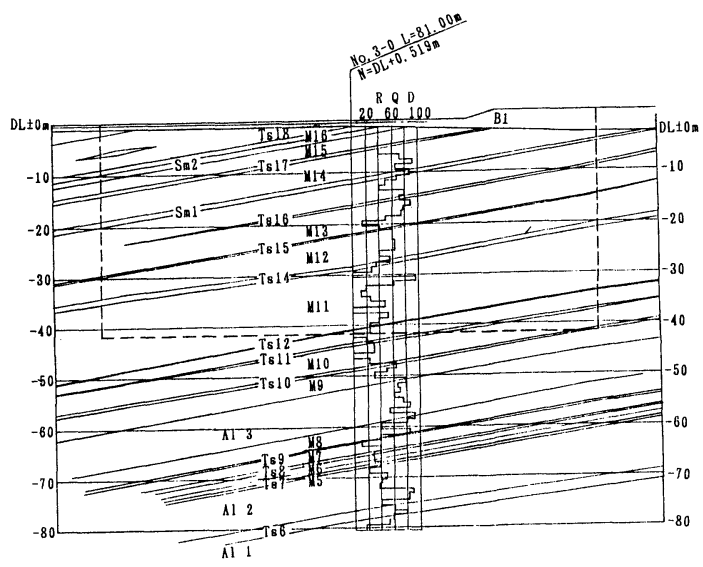

図一4 地質断面図 (N-S 断面)

表一2 土木工事工程表

\begin{tabular}{|c|c|c|c|c|c|c|c|}
\hline 年度 & 昭和 & 59 & 60 & 61 & 62 & 63 & 平成 \\
\hline 止水矢板工 & - & & & & & & \\
\hline 1 次掘削工 & - & & & & & & \\
\hline 埋㞍し盛土工 & & & & & & - & \\
\hline 親杭工 & & - & & & & & \\
\hline $\begin{array}{l}2 \text { 次掘削工 } \\
\text { (ロッフンー・吹付 C) }\end{array}$ & & & - & & & & \\
\hline 底部止水矢板工 & & & - & & & & \\
\hline 㑿水槽工 & & & - & & & & \\
\hline 底版 - 排水馅工 & & & & - & & & \\
\hline 晀壁工 & & & & & - & & \\
\hline
\end{tabular}

\section{(2) 設計 概 要}

駆体の構造設計においては，岩圧，地下水圧，地震の 影響, 温度応力等複雑かつ多種の荷重を受けるため, 本 体の応力解析はもちろん, 荷重の設定においてもこれら 複雑な状況を忠実にモデル化したFEMによる解析を 実施し, 最も厳しい荷重条件の把握およびこれに耐える 構造の設定を行っている. 特に, 岩盤の強度・変形特性 はひずみ依存性および時間依存性があることから，施工 状況を加味した逐次掘削解析を行い, 掘削時の岩盤の自 立性の確認, 完成後の岩圧のチェック等を行い, 設計精 度の向上を図っている。

設計フローを図一6に示す。

(1)止水矢板工

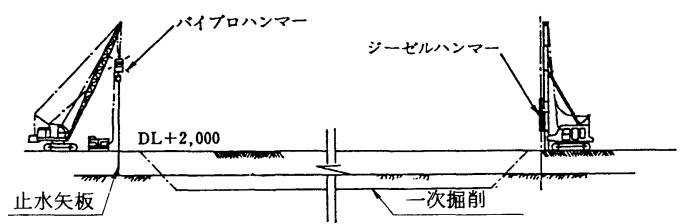

(2)掘 削 I

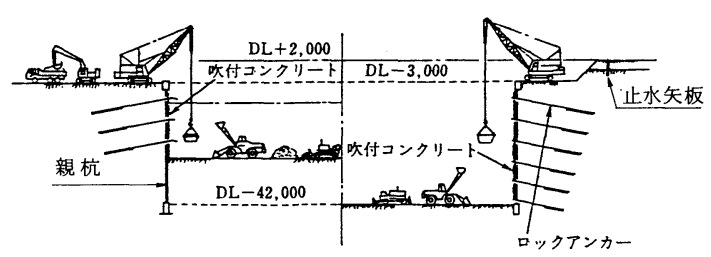

(3)側壁工（地中部）・底版工

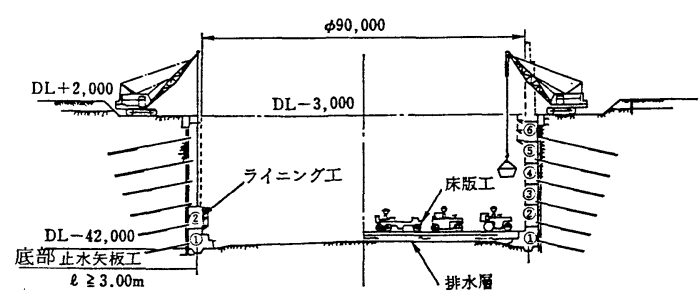

(4)側壁工（地上部）・埋民し盛土工

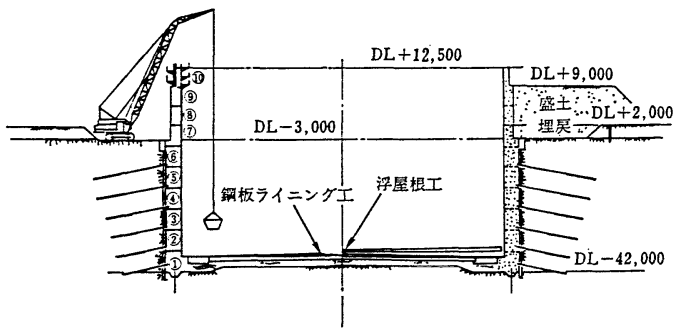

図一5 エ事フロー 


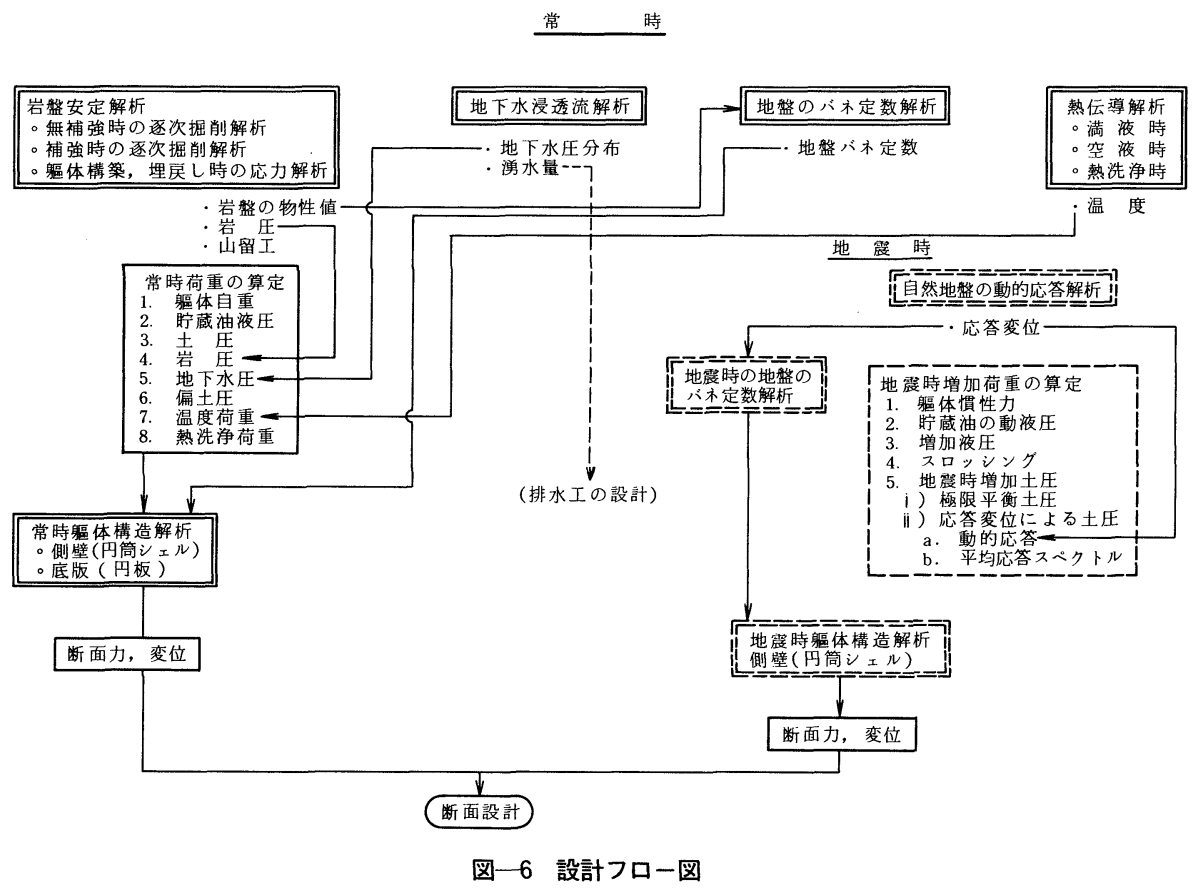

\section{3. 掘削工事の管理結果および設計の評価}

地中夕ンクは，泥岩中に構築するものであり，掘削に 伴う泥岩の性状変化は施工時の山留工および軀体に大き な影響を与える.このため，事前の地質調査および泥岩 特有の膨張性およびスレーキング性などの調査結果に基 づいて計画を行うとともに，施工時に際しては，地山の 変形, ロックアンカ一張力の測定を行い, さらに掘削壁 面の地層観察および周辺地盤の地下水の変動を観測しな がら地山の安定性，および設計の妥当性について検討を 行った.

以下にその概要について述べる.

\section{（1）泥岩の特性}

a) 設計用物性值

タンクの建設に先立って設計・施工に必要な詳細な地 質の分布, 岩盤状態, 岩質の物理的, 力学的性質を把握 することを目的に地質調査を実施し，この結果をもとに 表一3に示す設計用物性値を設定した.

b) 膨張特 性

一般に泥岩は，掘削時の応力解放等の応力変化により 吸水膨張を起こしやすいことが知られており ${ }^{1)}$, 長期間 にわたり膨張が続くと，側壁軀体が完成した後も泥岩の 膨張により岩圧が増加し，その程度によっては軀体の安 全性に問題が生じる.そこで, 掘削に先立ちタンク構築 深度の代表的 3 地点の泥岩のコアサンプリングを行い, 化学試験, 物理試験, 吸水膨張率試験および吸水膨張圧

\section{表一3 設計用物性值}

\begin{tabular}{|c|c|c|c|c|c|c|c|c|c|c|c|c|}
\hline & \multirow{2}{*}{\begin{tabular}{|c|} 
単位体皘 \\
重量 \\
$r$ \\
$\left(\mathrm{t} f / \mathrm{m}^{3}\right)$
\end{tabular}} & \multicolumn{2}{|c|}{$\begin{array}{l}\text { Coulomb } 9 \\
\text { 破溒基準 }\end{array}$} & \multicolumn{2}{|c|}{$\begin{array}{l}\text { Mohr } 9 \\
\text { 破壊基準 }\end{array}$} & \multicolumn{2}{|c|}{$\begin{array}{c}\text { 楥み領域の } \\
\text { 破㙼基準 }\end{array}$} & \multirow{2}{*}{\begin{tabular}{|c|} 
变形系数 \\
$\mathrm{E}_{0}$ \\
$\left(\mathrm{~kg} / \mathrm{cm} \mathrm{cm}^{2}\right)$
\end{tabular}} & \multirow{2}{*}{$\begin{array}{c}\text { ポアソン } \\
\text { 比 } \\
\nu_{a}\end{array}$} & \multirow{2}{*}{$\begin{array}{c}\text { 非線 形 } \\
\text { 変形特性 } \\
- \\
-\end{array}$} & \multicolumn{2}{|c|}{$\begin{array}{c}\text { クリープ } \\
\text { 定数 }\end{array}$} \\
\hline & & $\phi(0)$ & $\begin{array}{c}\mathrm{C} \\
\mathrm{kg} / \mathrm{f} / \mathrm{cm})\end{array}$ & $\begin{array}{c}\sigma \mathrm{t} \\
\left(\mathrm{kg} / \mathrm{f} / \mathrm{m}^{2}\right)\end{array}$ & $\begin{array}{c}\tau \gamma \\
(\mathrm{kgf} / \mathrm{cm})\end{array}$ & $\phi^{\prime}(0)$ & $\begin{array}{c}\mathrm{C}^{\prime} \\
(\mathrm{kg} g \mathrm{f} / \mathrm{cmt}\end{array}$ & & & & $\alpha$ & $\left(1^{\beta} /\right.$ day $)$ \\
\hline $\begin{array}{l}\text { 岩 } \\
\text { 篮 } \\
\text { I }\end{array}$ & 187 & 27.7 & 5.3 & 4.5 & 7.6 & 27.7 & 1.3 & 3,500 & 0.37 & $\begin{array}{l}\mathrm{E} / \mathrm{E} \\
0.75 \\
-\mathrm{R}+0.18 \\
0.75 \\
\times(1-\mathrm{R})\end{array}$ & 0.5 & 0.02 \\
\hline 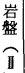 & 1.87 & 25.7 & 7.9 & 5.6 & 9.9 & 25.7 & 2.0 & 5,400 & 0.37 & " & 0.5 & 0.02 \\
\hline
\end{tabular}

(注) 岩盤(1)，(四の区分は困ー9に示す。

試験などを実施した。

試験の結果，吸水膨張率は $0.09 \sim 1.12 \%$ (平均 0.62 $\%$ ）であり，吸水膨張圧は $0.11 \sim 0.90 \mathrm{kgf} / \mathrm{cm}^{2}$ (平均 $\left.0.52 \mathrm{kgf} / \mathrm{cm}^{2}\right)$ であった. 吸水膨張率の值としては, 通 常の膨張性泥岩たとえば鍋立山トンネルの場合の膨張量 $(4 \sim 8 \%)^{2)}$ に比較するとそれほど大きな值ではない. また, 吸水膨張の時間依存特性は, 双曲線法で近似した 結果，60～240 日程度で最終膨張量の $90 \%$ を終了する ことが判明した。そのため，掘削終了から軀体構築まで の期間（約 4 か月）を考えると吸水膨張圧による軀体へ の影響はほとんどないものと判断できた.

c) スレーキング特性

一般に，泥岩は掘削面を大気中にさらしたまま放置し 乾湿を繰り返すと, 表面が風化しスレーキング現象を起 こす ${ }^{3)}$. 本工事では，掘削壁面の保護のために吹付けコ ンクリート $(t=80 \mathrm{~mm})$ を行うが，掘削から吹付けコ 
ンクリート施工までの間に側壁背面の注水設備の設置工 などにより 1 週間程度の放置期間がある。 そこで，この 間のスレーキングの性状の把握および有効な防止対策に ついて試験を行った。

試験の結果は以下のとおりである.

(1) 基本性状試験

スレーキング挙動を経時的物性変化で把握するため, 表一4 に示す方法で試験を行った。

試験の結果を図一7に示す. 掘削後の経過日数ととも に風化が進行し， 7 日経過時で $7 \sim 10 \mathrm{~cm}$ 程度の風化深 度となった。また，室内風化試験を行った結果，温度が 高いほど風化が進行することが判明した。

以上の試験結果および掘削面における風化状況からみ て，スレーキング防止対策が必要となった。

(2) スレーキング抑制試験

短期的なスレーキング対策としては，簡便にかつ安価 に施工できる工法として，泥岩の表面に被膜を作りス レーキングを防止する方法を採用した。 そのため，3つ の被膜材料の比較試験により, その効果の確認を行うこ ととした．各材料について，風化の程度を泥岩表面の剝 離深さで表わした結果を図一8に示す。これよりいずれ

\section{表一4 基本性状試験方法}
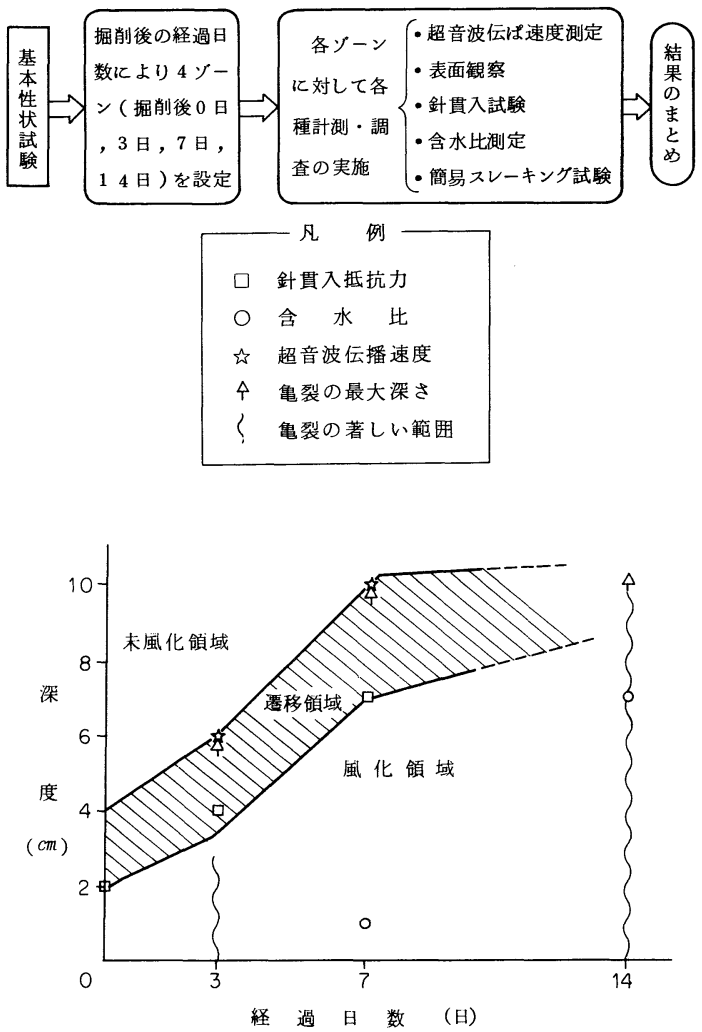

図一7 風化の進行状況 4
の対策工も無対策に比べて約 $1 / 15$ 程度となっておりそ の有効性が確認された.

本工事においては, 掘削後直ちに, 地山状態に応じて 上記 3 材料のうちから選定した材料により対策を行った 結果，スレーキングを防止することができた。

(2) 山留計画

山留計画にあたっては，設計用物性值を用いて，直線 すべり計算法および FEM による岩盤応力解析により 掘削時の検討を行った。ここに FEM による解析結果 を図一 $9 ， 10$ に示す．図一 9 から，掘削時の岩盤内応力 は岩盤の破壊基準に対して所要の安全率があり自立する ことが確認された。

しかし，図一10に示すように，掘削壁面の近傍では 引張応力が発生するため泥岩の進行性破壊の防止の観点 から，親杭・ロックアンカーによる補強を計画した。

ロックアンカーの導入力は, 岩盤内引張応力を岩盤の

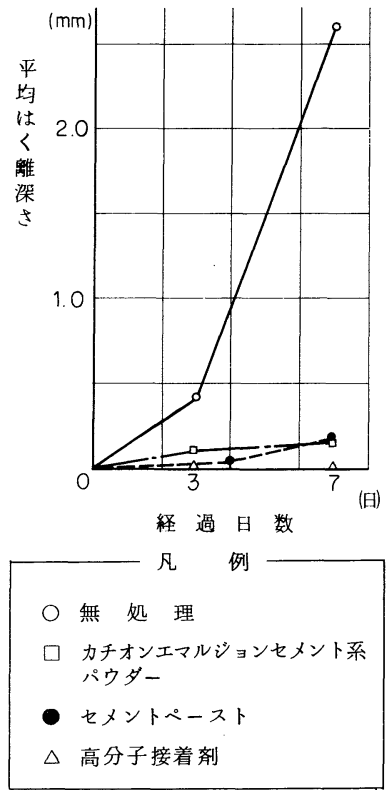

図一8 スレーキング抑制試験結果

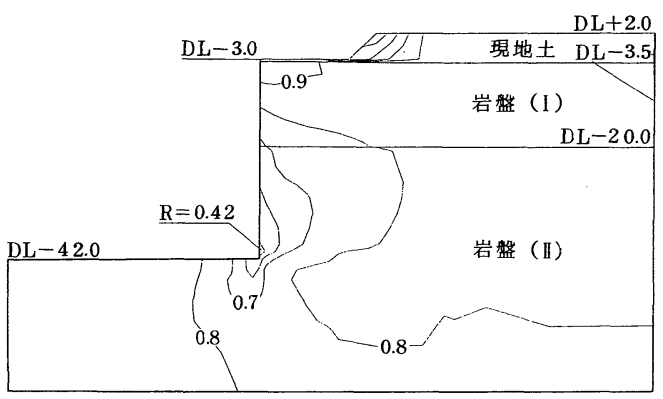

図一9 破壊接近度図 
引張強度の $1 / 10$ 以下にすることとし，プレストレスの 平均面分布荷重に換算して $1.5 \sim 4.0 \mathrm{tf} / \mathrm{m}^{2}$ で計画した.

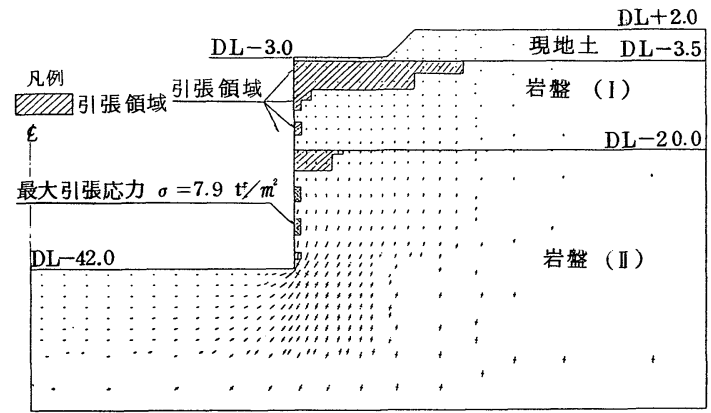

図一10 最小主応力図
なお，解析の結果から，掘削の進捗に伴う張力増加（あ と荷荷重）として，初期導入力の $10 \%$ を見込みロック アンカーの計画を行った.

ただし，実際は掘削の規模から考え岩盤の強度のばら つき，亀裂などの影響が予测されるため，本掘削工事に おいては, 後述するように綿密な計測管理体制による情 報化施工を行った.

\section{(3) 計測管理}

a) 管理方法

計測管理を次の方法で実施した。

(1) 地質観察

各掘削ステージごとに掘削壁面を観察し, 地山安定上 問題となるような弱層部, 異常湧水箇所などの分布, 規

表一5 掘削工事における計測項目一覧表

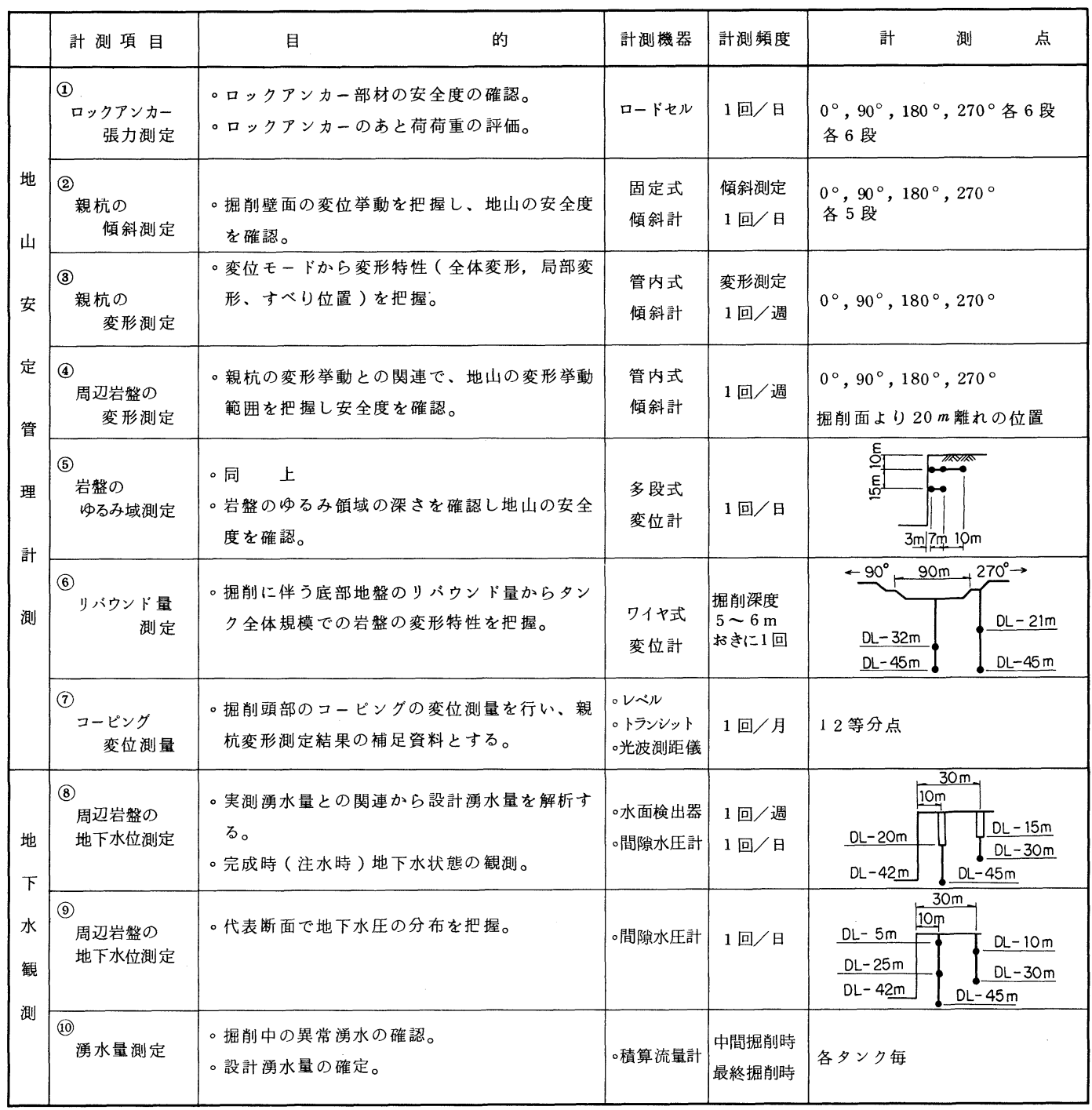




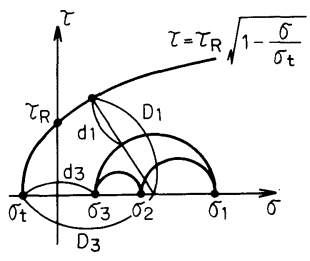

Mohr の破壊包絡線

破壊接近度 $R=\min \left(\frac{d_{1}}{D_{1}}, \frac{d_{3}}{D_{3}}\right)$

$R=1:$ 等方応力状態 (せん断応力 $=0)$ $R=0$ ：破壊状態

判定基準 : $R=\frac{d_{t}}{D_{i}} \geqq \frac{1}{3} \quad\left(F_{s}=\frac{D_{t}}{D_{t}-d_{t}} \geqq 1.5\right)$

図一11岩盤の破壊基準と破壊接近度 ${ }^{5)}$

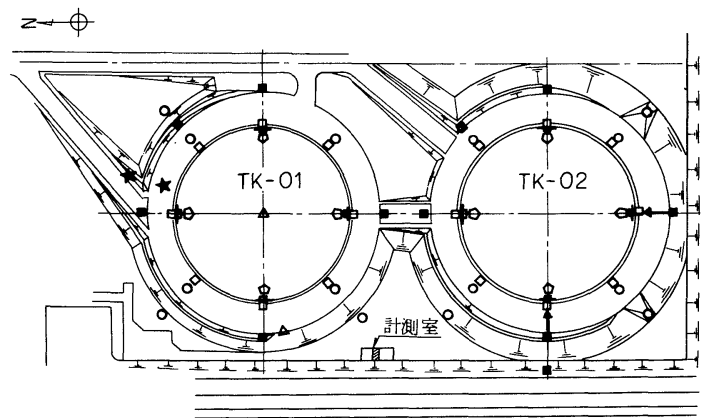

\begin{tabular}{|c|c|c|}
\hline 記号 & 测定項目 & 使用計器 \\
\hline 0 & 地下水位測定 & 間隙水圧計 \\
\hline 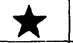 & 地下水圧測定 & 間隙水圧計 \\
\hline 0 & 親杭傾斜測定 & 固定式傾斜計 \\
\hline$\square$ & 親杭変形測定 & 管内式傾斜計 \\
\hline$\bigotimes$ & 周辺岩盤变形測定 & 管内式傾斜計 \\
\hline 口 & ロックアンカー張力測定 & 荷重計 \\
\hline$\longleftarrow$ & 岩盤のゆるみ域測定 & 多段式変位計 \\
\hline$\triangle$ & リバウンド測定 & ワイヤー式変位計 \\
\hline
\end{tabular}

図一12 計器設置位置図 (1 工区の例)

模，連続性を確認する.

(2) 計測

掘削に伴う地山および山留めの変形, ロックアンカー 張力, 周辺地盤の間隙水圧等の計測を行い, 管理基準に 照らして安全性の評価を行う.

\section{(3) 予測解析}

掘削途上の地質観察および計測結果に基づいて最終掘 削時点までの予測解析を行い, 安全性を確認し必要に応 じ詳細な検討を実施する.

b) 計测計 画

掘削工事期間中に実施した計測項目の一覧を表一5に 示す.また, 各計器の配置例を図一12 に示す.

$$
\text { TK- } 01
$$

TK- 03

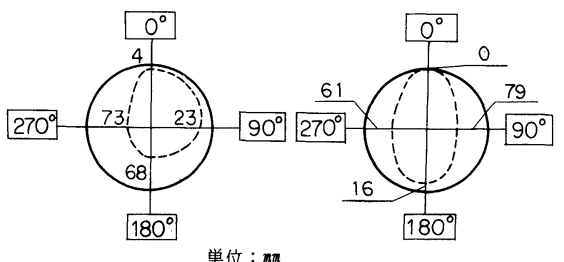

$$
\text { TK-02 単位: } m m
$$

TK-04

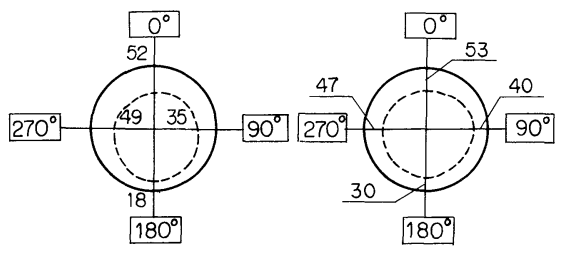

図一13最終掘削時における掘削壁面の最大变形量

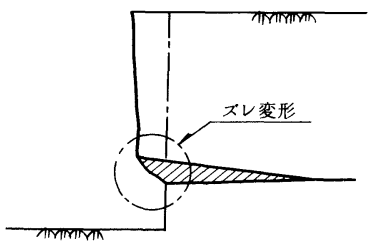

図一14 ずれ変形の形状

\section{c）計測管理の実績}

掘削途中の地山の変形およびロックアンカー張力測定 による局所的な特異性の幑候に対して, ロックアンカー の計画導入力の再配分や張力のあと荷荷重の一部見直し を行いながら掘削を進めたが，最終掘削時点における地 山の挙動は当初予測值にほぼ近い值であった。以下に主 要な計測管理の結果について述べる.

i）掘削壁面の変形

最終掘削時における各タンクの鉛直壁面の最変形量を 図一13に示す。

この変形量は次に示す 4 つの要因に分類できる.

(1) 応力解放による変形

(2) 泥岩の吸水膨張による変形

(3) 掘削壁面付近の局所的な地質要因によるずれ変 形注1)

(4) 地山の異方性による変形

実測された変形量および変形分布と吸水膨張試験の結 果より想定した吸水膨張による変形量に基づいて, 上記 要因別に分析した各変形量. 結果を表一6に示す.

(1)および(2)の要因による変形は，当初設計に見込んで けたものであるが，実測值は設計值を下回る結果となっ ている.ただし(3)おび(4)の要因による変形については, 設計段階では定量的な把握が困難であるため, 施工中の

注 1）親杭に設置した管内式傾斜計により測定された局所的 な変形。 
表一6 壁面の要因別変形量の比較

\begin{tabular}{|c|c|c|c|c|c|c|c|}
\hline & TK- 01 & TK-02 & TK -03 & TK -04 & 平 & 備 \\
\hline \multicolumn{2}{|c|}{$\begin{array}{c}\text { 計測によるる } \\
\text { 最大変形量 }\end{array}$} & 7.3 & 5.2 & 7.9 & 5.3 & 6.4 & A \\
\hline \multicolumn{2}{|c|}{$\begin{array}{r}\text { (2) 吸水膨張による } \\
\text { 変形量 }\end{array}$} & \multicolumn{5}{|c|}{2.0} & B \\
\hline \multicolumn{2}{|c|}{$\begin{array}{r}\text { (3),(4)を要因とする } \\
\text { 変形量 }\end{array}$} & 2.9 & 1.9 & 3.9 & 1.4 & 2.5 & C \\
\hline \multirow{2}{*}{\begin{tabular}{|l|} 
(1) \\
志力解放 \\
による \\
変 形 量 \\
\end{tabular}} & 実測 & 2.4 & 1.3 & 2.0 & 1.9 & 1.9 & $\mathrm{D}=\mathrm{A}-(\mathrm{B}+\mathrm{C})$ \\
\hline & 設 計 & \multicolumn{5}{|c|}{2.5} & $\mathrm{E}$ \\
\hline
\end{tabular}

$\mathrm{O}^{\circ}($ 方位 $\mathrm{N})$ 断面

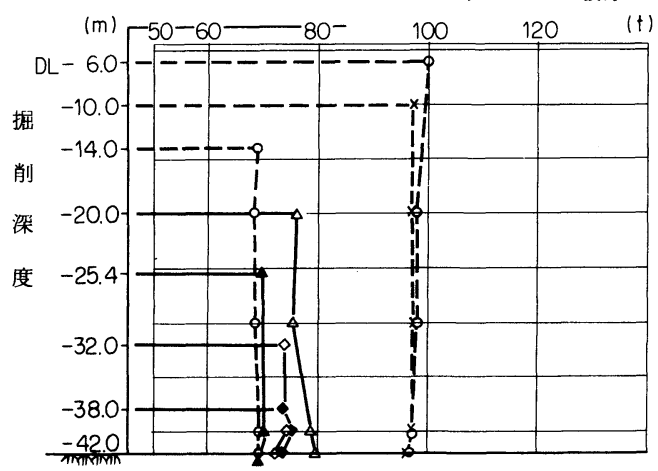

$90^{\circ}($ 方位 $\mathrm{E}$ ) 断面

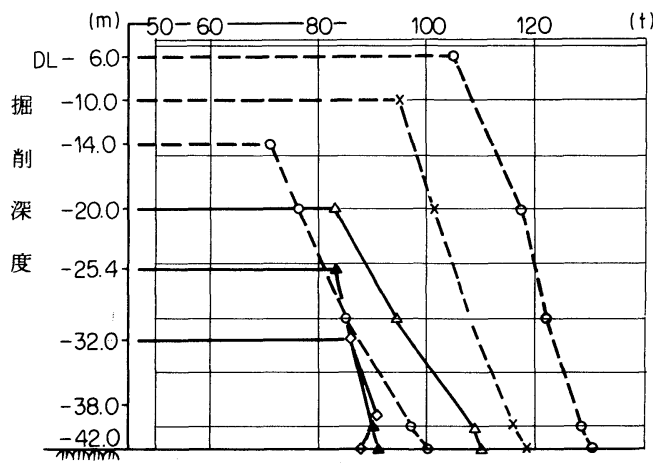

図一15 掘削の進行に伴うロックアンカー張力の変化

計測デー夕等に基づいて掘削時の安定の検討を行うほ か, 軀体への影響について検討を行い安全であることの 確認を行った.

\section{ii ）ロックアンカー張力}

掘削の進捗に伴う張力増加（あと荷荷重）は，同一夕 ンクでも場所により異なる傾向を示した．代表的な傾向 を示す 2 地点の測定結果を図一15に示す.

ロックアンカー張力の増加傾向を統計的に表わすと図 一16に示すとおりである.

図一 16 より，あと荷荷重の平均值は，初期導入力の $15 \%$ 程度であるが，あと荷荷重が設計値を上回る箇所

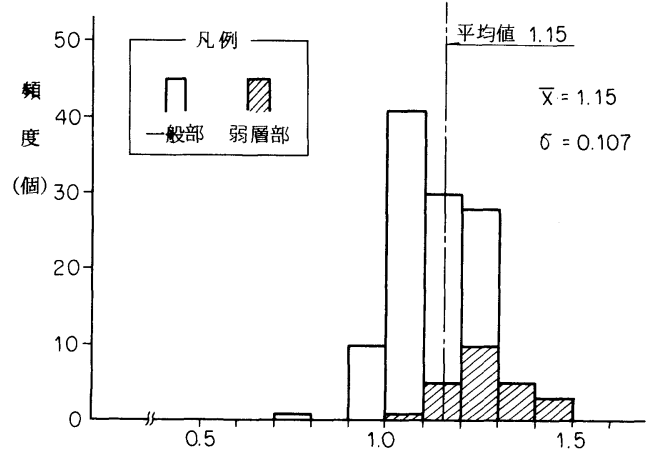

（最終張力/初期導入力）

図一16 初期導入カに対するロックアンカー張力の比率 (最終掘削時)

は，ほとんど局所的な地質的要因によるずれ変形を生じ た箇所と一致している。これらの箇所は，掘削の初期段 階において, 親杭および親杭から約 $20 \mathrm{~m}$ 離れた周辺地 盤の変形測定結果から予測されたため, 当初計画のあと 荷荷重 $10 \%$ を平均で $20 \%$ に引上げてアンカー計画の 見直しを行った．その結果, 最終掘削時点においてもア ンカー張力は，管理限界値内におさめることができた。

\section{iii）掘削壁面の地質状況観察}

掘削途中, 壁面の全周の観察によりボーリング等の事 前調査では得られなかった詳細な地質状況の確認がで き, 計測の結果と照らすことにより現象の的確な把握と 予測解析が可能となり必要な山留めの処置を適切かつ迅 速に行うことができた。

\section{（4）設計の妥当性の評価}

地中タンクの大部分は, 岩盤中に構築されることから, 軀体の設計は岩盤条件に大きく左右される，そのため， 掘削時における計測管理および試験結果に基づいて岩盤 条件にかかわる設計の妥当性について総合的な検討を 行った．以下主要な検討項目について述べる。

a）地盤のばね定数の評価

岩盤中の地盤のばね定数を評価するためには，掘削壁 面から奥行き方向の変形係数の分布とその值を確認する 必要がある. そのため，(1)水平多段式変位計による掘削 壁面付近のひずみ分布の測定，(2)新鮮岩盤部の変形特性 を評価するためのタンク中央部でのリバウンド量の測定 および，(3)掘削壁面近傍での鉛直ボーリングによる孔内 水平載荷試験を実施した.

これらのデータから図一17に示す手順で掘削壁面部 の岩盤の変形係数の值およびその分布を求め, これに基 づいて地盤のばねの評価を行った結果を以下に述べる.

i）水平多段式変位計の計測結果

掘削途中，表一 5 に示す水平多段式変位計の測定によ 


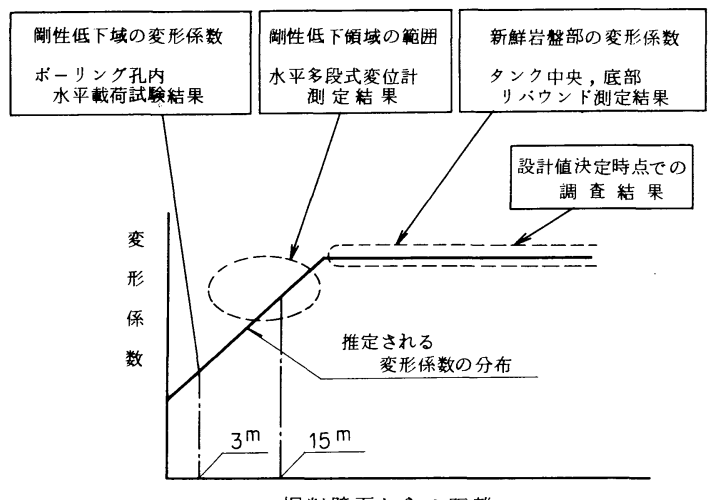

掘削壁面からの距離

図一17 变形係数の分布推定に用いるデータの位置つけけ

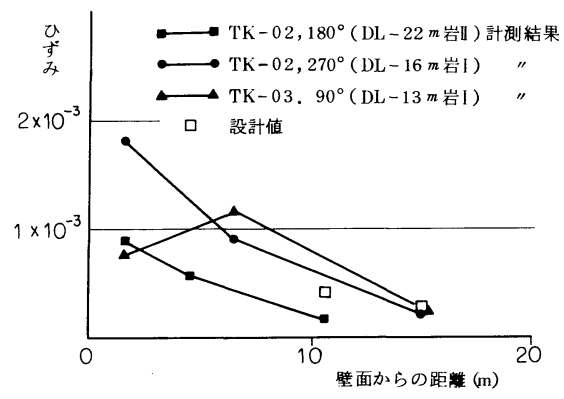

図一18 岩盤の剛性低下領域の広がり

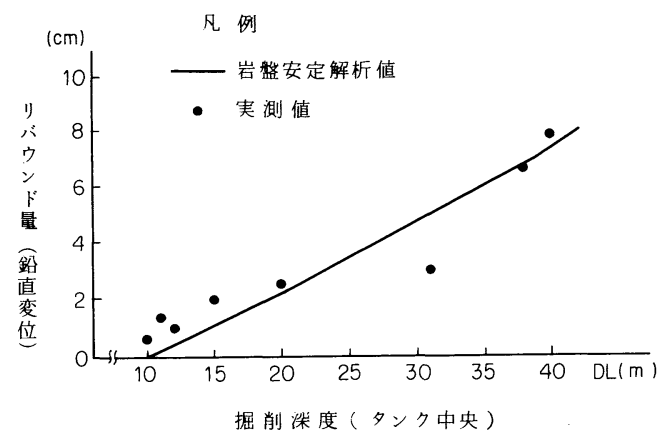

図一19掘削深度とリバウンド量の関係

る岩盤のひずみ分布から掘削による影響範囲を評価でき る. 計測の結果を図一18に示すが,これより変形係数は, $10 \sim 15 \mathrm{~m}$ 程度付近で設計値とほぼ等しくなっている.

ii ）リバウンド量の測定結果

タンク底部の中央部におけるリバウンド量の計測結果 と設計値とを図一19に示す.

これより，リバウンド量の実測值は設計值とほぼ合っ ており,タンク全体規模での岩盤部の変形係数の妥当性 が確認された。

iii）孔内水平載荷試験結果

掘削後, 壁面から $3 \mathrm{~m}$ の位置で実施した孔内水平載

\section{表一7 孔内水平載荷試験結果による变形係数值}

(単位 : $\mathrm{kg} f / \mathrm{cm}^{2}$ )

\begin{tabular}{|cc|c|c|c|c|c|}
\hline & 設 計値 & TK-01 & TK-02 & TK-03 & TK-04 \\
\hline 岩 & I & 1,167 & 1,650 & 2,235 & 2,371 & 1,273 \\
\hline 岩 & II & 1,800 & 3,558 & 6,085 & 3,273 & 8,370 \\
\hline
\end{tabular}

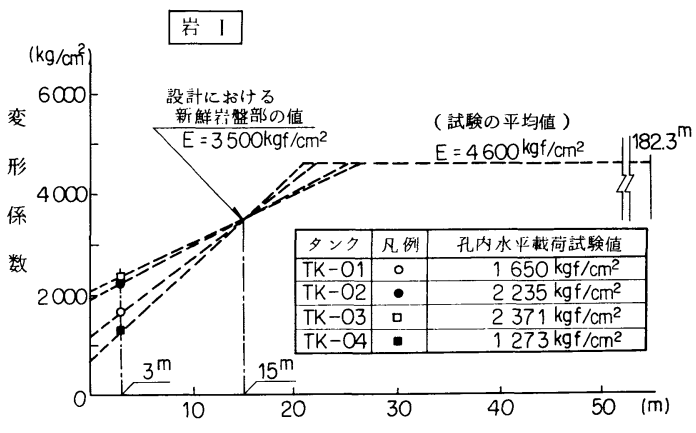

掘削壁面からの距離

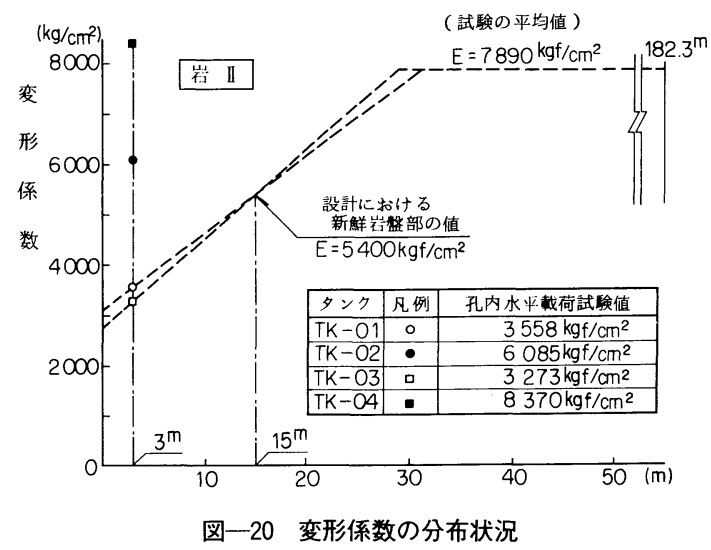

荷試験の結果は，表一7に示すように掘削によるゆるみ 領域として設定した変形係数を上回る值を示している.

iv）変形係数の分布状況

以上の計測・試験の結果から, 掘削壁面付近の変形係 数の值およびその分布を, 図一20に示すように設定し た。

V）地盤のばね定数の評価

図一20の地山の変形係数の分布から, FEM 解析に より，地盤のばね定数を算定すると表一8のとおりとな る. いずれのタンクについても設計值を上回っており軀 体は安全であると判断できる.

b）岩圧の妥当性

軀体構築後の盛土荷重による岩盤部の側方変形を, 軀 体で拘束することにより軀体に岩圧が作用する. この場 合の岩圧は, 主として岩盤の変形係数により左右される 


\section{表一8 計測結果から算出したばね定数}

(単位 $: \mathrm{kgf} / \mathrm{cm}^{2}$ )

\begin{tabular}{|c|c|c|c|}
\hline 岩区分 & タンク & $\begin{array}{l}\text { 当初設計での } \\
\text { ハネ定数 }\end{array}$ & $\begin{array}{l}\text { 本検討での見直し } \\
\text { バネ定数 }\end{array}$ \\
\hline \multirow{4}{*}{ 岩 I } & 01 & \multirow{4}{*}{0.55} & 0.60 \\
\hline & 02 & & 0.65 \\
\hline & 03 & & 0.65 \\
\hline & 04 & & 0.56 \\
\hline \multirow{4}{*}{ 岩 I } & 01 & \multirow{4}{*}{1.20} & 1.49 \\
\hline & 02 & & ※ \\
\hline & 03 & & 1.47 \\
\hline & 04 & & $※$ \\
\hline
\end{tabular}

※ボーリングれ水平載荷試験の結果, 壁面より $3 \mathrm{~m}$ 地点の 変形係数の值が設計值に比へ 3 倍以上であり, 明らかにバネ 定数は設計値より大きい。

が，実測に基づく変形係数は設計値以上の值であること が判明しており, 設計岩圧の評価は妥当であると判断で きる.

また，泥岩の吸水膨張による影響は，前述したように 岩圧として軀体に作用しないが，ちなみに，膨張圧試験 で求めた膨張圧をそのまま軀体に作用するとして軀体応 力解析を行っても, 軀体の応力は許容応力度内であり, 軀体の安全上問題ないことを確認している.

\section{4. あとがき}

今回の泥岩の大規模掘削工事においては, 設計上多く の懸案事項があったが,

(1) 泥岩性状に関する事前の調査, 試験の実施.
(2) 掘削時の地質観察および計測の実施.

(3) 地質観察および計測に基づく予測解析と解析結果 の工事へのフィードバックの実施.

により，安全かつ経済的に掘削工事を予定工期内で完了 することができた．また，施工中の試験・計測の結果に よる岩盤物性の評価により設計の妥当性が確認された. これら，西基地の工事から得られた数多くのデー夕およ び知見は, 現在工事を開始している東基地のみならず, その他多くの同種工事に反映できるものと考える.

最後に, 本工事の計画, 設計, 施工にあたって終始ご 指導をいただいた秋田石油備蓄(株)技術審査委員会（委 員長 奥村敏恵東大名誉教授）の諸先生方ならびに関係 各位に対し深く感謝の意を表する次第である.

\section{参 考 文 献}

1）土木学会編：土木技術者のための岩盤力学, pp.159〜 163.

2) 大塚・豊島：膨張性地山での苦闘一北越北線鍋立山トン ネルの計測と施工，トンネルと地下, Vol.11, No.1, 1980.1.

3）土質工学会編：日本の特殊土, pp. 320 327.

4）永田・山田・関屋：掘削泥岩表面部の風化現象の現場測 定例, 第 20 回土質工学研究発表会, pp. 909 910, 1985.1.

5）谷本・佐々木：岩盤，断層，破砕帯の各変形特性の試料 の強度による表現の試みとその検討, 鹿島建設技術研究 所年報, Vol. 22, 1984 .

（1988.11.18 • 受付） 